\title{
УЯВЛЕННЯ МОЛОДІ ПРО ЖИТТЕВИЙ УСПІХ: ЦІННІСНИЙ АСПЕКТ ДОСЛІДЖЕННЯ
}

3'ясовано, що в поняття життєвого успіху молодь зазвичай вкладає добрі стосунки, соціальне визнання, багатство, професіоналізм, кар'єру, впливовість, творчу самореалізацію. Зауважено, що найчастіше уявлення про життєвий успіх пов'язані $з$ добрими стосунками і творчою самореалізацією. За допомогою методики вивчення цінностей особистості Ш. Шварца досліджено зв'язок цих уявлень і цінностей. Виявлено, зокрема, провідні цінності молоді: цінності досягнення, самостійності, гедонізму, безпеки і доброзичливості, які пов'язано з тенденцією відкритості до змін і самозвеличення (а не до трансцендентності й консерватизму). Встановлено, що добрі стосунки базуються на цінностях конформності, традиції, доброзичливості й безпеки; соціальне визнання - на цінностях доброзичливості й універсалізму, а багатство - на цінностях конформності, гедонізму і влади. Із професіоналізмом пов'язано цінності конформності, традиції, доброзичливості, універсалізму, самостійності, стимуляції, досягнення і безпеки, з кар'єрою - цінності конформності й досягнення, а 3 впливовістю - цінності стимуляції і влади. Наголошено, що для молоді, яка обрала творчу самореалізацію, важливою $є$ цінність самостійності, тоді як молодь, у якої превалюють цінності конформності й універсалізму, великого значення в досягненні успіху надає виваженості, ризик же пов'язується із цінністю стимуляції. Помічено, що молодь, яка визнає передусім цінність самостійності, заперечує пріоритет соціальних зв'язків у досягненні успіху і більше покладається на себе; при цьому вона, досягнувши певних результатів, відкрито демон-струє свою позицію і готова ділитися своїми успіхами з оточенням.

Ключові слова: уявлення, образ, життєвий успіх, життєві орієнтири, цінності, молодь.

\section{Yu. Vinkov}

\section{YOUTH'S BELIEFS ABOUT LIFE SUCCESS: VALUE ASPECT OF RESEARCH}

It is found out that the concept of life success among young people usually includes good relations, social recognition, financial stability, professionalism, career, influence, and creative self-realization. It is noticed that the most frequent idea about life success is related to good relations and creative self-realization. Connection of these beliefs and values were studied by means of personality values methodology (Sh. Schwarz). Following leading values were identified, in particular, among young people: values of achievement, independence, hedonism, safety, and goodwill, related to the tendency of openness to change as well as self-aggrandizement (but not to transcendence and conservatism). It is established that good relations are based on values of conformity, tradition, goodwill, and safety; social confession corresponds with values of goodwill and universalism, and wealth is based on values of conformity, hedonism, and power. Professionalism relates to values of conformity, tradition, goodwill, universalism, independence, stimulation, achievement and safety; the 
career is connected with conformity and achievement, while influence links to stimulation and power values. It is emphasized that young people, who prioritize creative self-realization, also recognize the value of independence, while young people, who tend to values of conformity and universalism, consider balance as a key factor of life success and risk as a factor linked to stimulation value. It is observed that young people, who acknowledge independence value foremost, usually deny priority of social connections for success achievement and rely more on themselves; when certain results are achieved, such young people openly demonstrate their position and are open to sharing their success with others.

Key words: beliefs, image, life success, life landmarks, values, youth.

Постановка проблеми. Динамічний розвиток різних сфер суспільного життя і вплив на цей розвиток сучасних світових тенденцій, як-от: демократизації політичної системи, глобалізації та лібералізації української економіки і зрештою інтеграції ії у світовий економічний простір, поширення сучасних технологій передавання інформації неодмінно спричинюють зрушення в системі цінностей українського суспільства. Найбільш чутливими до цих впливів є молодь, яка швидко опановує нові технології, набуває досвіду користування ними. Це неодмінно впливає на формування їі уявлень про життєвий успіх. Тому актуальним наразі лишається питання, які уявлення про життєвий успіх $\mathrm{i}$ які цінності переважають у сучасної молоді. Отже, вивчення уявлень молоді про життєвий успіх та їх зв'язок із цінностями є досить перспективним дослідницьким напрямом, що передбачає розширення меж передусім емпіричного знання.

Аналіз останніх досліджень і публікацій та виокремлення невирішених частин загальної проблеми. На сьогодні проблема дослідження уявлень широко представлена в психології. У межах діяльнісного підходу образи та уявлення вивчали, наприклад, Т. Березіна, А. Гостєв, О. Леонтьєв, В. Пєтухов, В. Рубахін, С. Смирнов та ін. У західній психології великої популярності набула теорія соціальних уявлень, значний внесок у розвиток якої зробили С. Московічі, Ж. К. Абрік, Д. Жоделе. Приділяють увагу цій проблематиці і наші вітчизняні дослідники, зокрема І. Жадан, О. Міщенко, В. Москаленко, Н. Хазратова.

Проте кількість емпіричних досліджень, присвячених вивченню уявлень про життєвий успіх, поки що не така вже й велика. У цих роботах виявлені явища в основному констатуються та описуються, утім не завжди пояснюються. Здебільшого це дослідження, що розкривають статеворольові та міжпоколінні особливості уявлень про життєвий успіх. Так, К. Мелащенко звертає увагу на статеворольові аспекти проблеми успіху; дослідниця виявила, що жінки прагнуть реалізуватися насамперед у приватній, міжособистісній сфері, тоді як чоловіків більше цікавлять досягнення в публічній сфері (кар'єра, досягнення престижу, 
високого статусу тощо). Разом з тим констатовано відхід від традиційного бачення самими жінками своєї ролі в публічній сфері та готовність передати частину своїх обов'язків у приватній сфері чоловікам [1]. М. Андросенко виявила, що якщо у чоловіків успіх здебільшого асоціюється 3 наявністю соціальних зв'язків, матеріальним забезпеченням, владою та участю в політичній діяльності, то в жінок - із наявністю здоров’я, хорошої освіти і сім’ї [2]. Дослідження О. Гудзенко зосереджені головним чином на відмінностях в уявленнях старшого і молодого поколінь. Якщо старше покоління досягнення успіху пов'язує передусім з умінням відповідати нормам, правильно використовувати наявні канали соціальної мобільності, то в уявленнях молоді важливу роль відіграють уміння знайти нестандартні можливості та удача. Для представників як молодого, так і старшого покоління показником успіху $\epsilon$ високий матеріальний статус і професіоналізм. Проте спостерігаються й очевидні міжпоколінні відмінності: для представників старшого покоління важливо почувати себе грамотним фахівцем, а для молодого добре оплачуваним фахівцем [3]. Дослідження Р. Шаміонова і А. Тугушевої ставило за мету з'ясувати, як молодь розуміє успіх, що для неї $є$ важливим у житті. Виявилося, що для молодих успіх асоціюється 3 особистісними якостями (цілеспрямованість, упевненість, прагнення саморозвитку), роботою (улюблена робота, кар'єра) та характеристиками соціальних стосунків (статус у суспільстві, здатність впливати, підтримка найближчого оточення) [4].

У зв’язку з цим значний інтерес становить дослідження ціннісного аспекту уявлень молоді про життєвий успіх, що мало досі досліджувався в сучасній вітчизняній психології. Відповідно, залишається відкритим і питання, як співвідносяться між собою життєвий успіх i цінності. 3 огляду на перспективність розроблення цієї проблематики важливим завданням соціальної психології $є$ емпіричне вивчення ціннісної сторони проблеми життєвого успіху.

Мета статті: дослідити ціннісний аспект уявлень молоді про життєвий успіх, а також виявити зв'язок цінностей із такими чинниками, як удача, ризик, соціальні зв'язки, загальноприйняті норми і правила в досягненні життєвого успіху.

Виклад основного матеріалу дослідження. Емпіричне дослідження проводилося на базі Київського національного університету імені Тараса Шевченка, Львівського національного університету імені Івана Франка, Чернігівського національного технологічного університету, Київського національного економічного університету імені Вадима Гетьмана, Таврійського національного університету імені Володимира Вернадського. Кількість опитаних становила 310 осіб. Це була студентська молодь віком від 17 до 25 років, що навчалася за різними напрямами гуманітарних спеціальностей (психологія, економіка, біологія, інформатика, соціальна робота, політологія, соціологія тощо). 
Емпіричне дослідження мало такі завдання:

1) визначити, які життєві орієнтири як показники життєвого успіху і які цінності є найбільш поширеними серед молоді;

2) виявити, які цінності є провідними залежно від життєвих орієнтирів молоді;

3) дослідити зв'язок цінностей із такими чинниками в досягненні життєвого успіху, як удача, ризик, соціальні зв'язки, загальноприйняті норми і правила, а також із ставленням оточення до успіхів, визнанням або знеціненням своїх досягнень, упевненістю й задоволеністю в досягненні життєвого успіху.

Процедура емпіричного дослідження. Відповідно до першого завдання учасникам було запропоновано з переліку досягнень у різних сферах життєдіяльності обрати ті, що, на їхню думку, свідчать про життєвий успіх, та оцінити, яке досягнення як показник успіху займає перше місце в їхньому житті. У переліку для оцінювання були представлені такі досягнення: добрі стосунки, соціальне визнання, багатство, професіоналізм, кар'єра, впливовість, творча самореалізація. Найчастіше з переліку пропонованих досягнень респонденти обирали добрі стосунки і творчу самореалізацію (відповідно 37,9 і 24,5\% опитаної молоді). Це свідчить про те, що для молоді найбільш важливими 3 погляду досягнення життєвого успіху є сфери, пов'язані з міжособовими стосунками і творчою самореалізацією, менше значення мають кар'єрна (12,4\% опитаних), професійна $(10,5)$, владна $(5,7)$, сфера соціального визнання $(3,8)$ і фінансова $(3,8 \%)$.

Щоб дослідити цінності студентської молоді, ми скористалися методикою вивчення цінностей особистості Ш. Шварца [5]. У результаті було визначено рівень прояву таких цінностей, як конформність, традиції, доброзичливість, самостійність, універсалізм, стимуляція, гедонізм, досягнення, влада, безпека. Згідно з даними нашого дослідження, найбільш популярними серед молоді є цінності досягнення, самостійності, гедонізму, безпеки і доброзичливості, а найменше - цінності традиції. Проміжне місце займають конформність, влада, стимуляція, універсалізм (рис. 1). Такий розподіл свідчить про те, що в ціннісному самовизначенні молоді визначальною $є$ тенденція відкритості до змін і самозвеличення, а не прагнення до трансцендентності й консерватизму. I це характерно для молоді загалом.

Друге завдання полягало у визначенні провідних цінностей залежно від того, які життєві орієнтири займають центральне місце в структурі уявлень молоді про життєвий успіх. Для цього було застосовано Н-критерій Краскела - Уоллеса та U-критерій Манна - Уітні. 


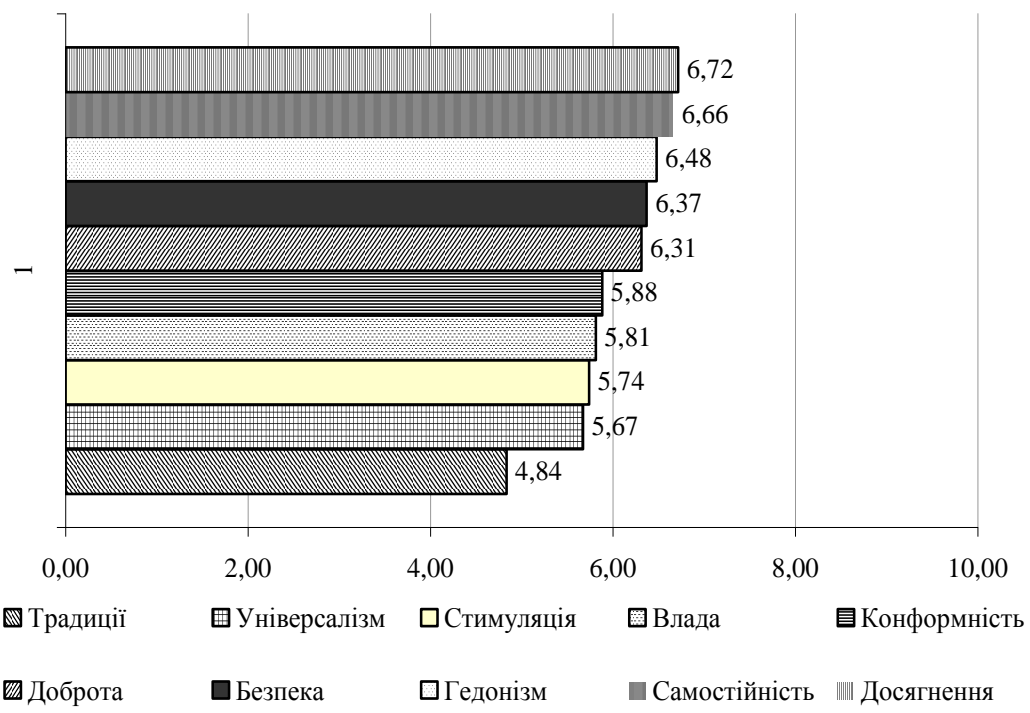

Рис. 1. Розподіл середніх значень за методикою вивчення цінностей особистості Ш. Шварца

Щоб виявити зв'язок ролі того чи того чинника життєвого успіху (удачі, ризику, соціальних зв'язків, загальноприйнятих норм і правил, ставлення оточення до успіхів, визнання або знецінення своїх досягнень, впевненості і задоволеності в досягненні життєвого успіху) із ціннісними орієнтаціями молоді, було використано розроблений на основі методу семантичного диференціала інструментарій. У нашому дослідженні семантичний диференціал дає змогу вивчати складники семантичних просторів уявлень молоді про життєвий успіх. Цей інструментарій складається 38 біполярних шкал, що відображають два протилежні за значенням твердження: орієнтація на удачу - орієнтація на себе, орієнтація на ризик - орієнтація на виваженість, орієнтація на соціальні зв'язки - орієнтація на себе, орієнтація на порушення норм i правил - орієнтація на дотримання цих норм і правил у досягненні успіху, упевненість - зневіра в досягненні успіху, визнання - знецінення своїх успіхів, позитивна - негативна оцінка оточенням своїх успіхів, задоволеність - незадоволеність своїми успіхами. Щоб виявити шуканий зв'язок, було застосовано кореляційний аналіз за критерієм Спірмена.

Запропоновані твердження оцінювалися так: досліджувані обирали одне 3 двох (протилежних за змістом) тверджень та оцінювали, відповідно, свій вибір за 3-бальною шкалою, де 3 бали - максимальне значення, яке означає, що цей чинник відіграє дуже важливу роль у 
досягненні успіху, а 1 бал дається в разі невеликої переваги цього чинника над іншим. Подальше обчислення значень цих протилежних за змістом тверджень здійснювалося за 6-бальною шкалою: мінімальних значень (від 1 до 3 балів) набувало твердження, розташоване зліва, а максимальних (від 4 до 6 балів) - твердження, що справа.

Відповідно до завдань дослідження слід було визначити, як цінності проявляються залежно від життєвих орієнтирів, які є складником уявлень молоді.

Як видно з рис. 2, цінність конформності найбільшою мірою виражена в молоді, що обрала за показник життєвого успіху добрі стосунки $(\mathrm{Rcep}=162,26)$, соціальне визнання $(\mathrm{Rcep}=172,38)$, багатство $(\operatorname{Rcep}=163,83)$, професіоналізм $(\operatorname{Rcep}=187,47)$ і кар'єру $(\operatorname{Rcep}=161,01)$, а найменшою мірою - у тих, хто обрав впливовість $(\mathrm{Rcep}=120,94) \mathrm{i}$ творчу самореалізацію $(\mathrm{Rcep}=132,7)$. Це свідчить про те, що для тих, хто обрав як мірило життєвого успіху добрі стосунки, соціальне визнання, багатство, професіоналізм і кар'єру, найбільш важливими в житті є стримування та уникнення дій, що можуть завдати шкоди іншим людям, або дій, що не відповідають соціальним очікуванням. Ця ж цінність $є$ найменш важливою для тих, хто обрав впливовість і творчу самореалізацію, що відбиває протилежну позицію в досягненні успіху - коли потрібно проявити винахідливість у пошуку рішень, що може викликати опір оточення та засудження з його боку.

Зв'язок цінності конформності з такими чинниками досягнення успіху, як удача, ризик, виваженість, соціальні зв'язки, загальноприйняті норми і правила, далеко не однозначний. Кореляційний аналіз за критерієм Спірмена показав, що серед перерахованих чинників найсильніший зв'язок із конформністю має виваженість $(\mathrm{r}=0,117, \mathrm{p}<0,05)$. Це означає, що молодь, схильна до консерватизму, уникає зазвичай у житті зайвого ризику. Також ця молодь демонструє впевненість у тому, що досягне успіху $(\mathrm{r}=-0,136, \mathrm{p}<0,05)$, свою задоволеність $(\mathrm{r}=-0,131$, $\mathrm{p}<0,05)$ і визнає, що має успіхи, якими може пишатися $(\mathrm{r}=0,140$, $\mathrm{p}<0,05)$.

Цінність традиції найбільш важлива для тієї молоді, що обрала добрі стосунки $(\mathrm{Rcep}=164,34)$, соціальне визнання $(\mathrm{Rcep}=180,96) \mathrm{i}$ професіоналізм $(\operatorname{Rcep}=191,97)$, а найменш важлива - для тієї, яка понад усе цінує багатство $(\operatorname{Rcep}=120,92)$, впливовість $(\operatorname{Rcep}=121,47)$ і творчу самореалізацію $(\mathrm{Rcep}=136,3)$. Ця цінність посідає проміжне місце в житті тих, хто обирає кар'єру $($ Rcep $=154,08)$. Цінність традиції для молоді, що обрала добрі стосунки, соціальне визнання і професіоналізм, полягає в тому, що прийняття звичаїв і норм, які панують у культурі, їх дотримання й участь у житті референтної групи $\epsilon$ важливим складником їхнього життя, і в їхньому розумінні такий шлях може привести до успіху (рис. 2). 


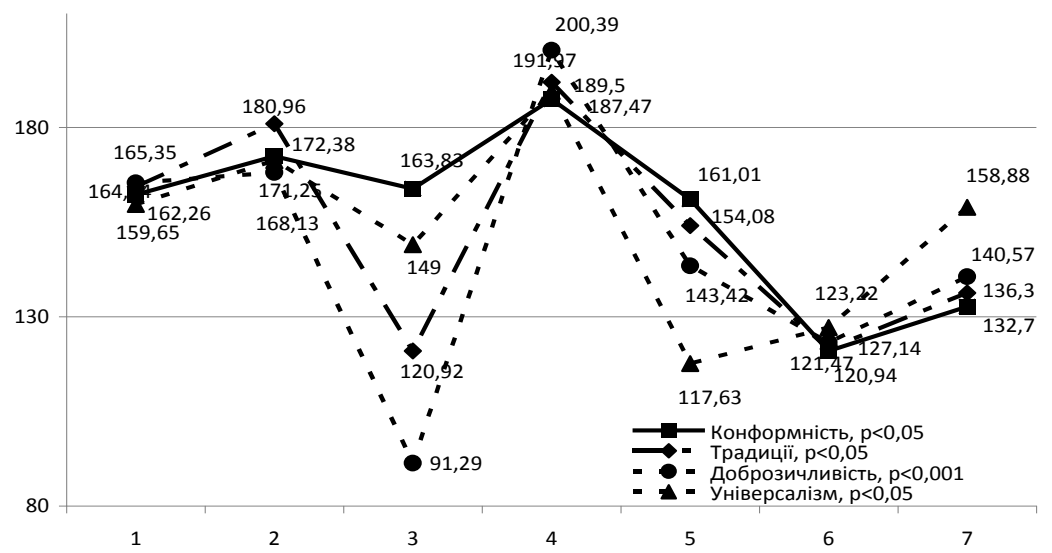

Примітки: 1 - добрі стосунки, 2 - соціальне визнання, 3 - багатство, 4 - професіоналізм, 5 - кар'єра, 6 - впливовість, 7 - творча самореалізація.

Рис. 2. Розподіл значень за методикою вивчення цінностей особистості Шварца залежно від життєвих орієнтирів, які молодь обрала як показник життєвого успіху (Н-критерій Краскела - Уоллеса, Rcep)

Значення цінності доброзичливості виявилося більшим у молоді, що обрала добрі стосунки $(\mathrm{Rcep}=165,35)$, соціальне визнання $(\mathrm{Rcep}=168,13)$ та професіоналізм $(\operatorname{Rcep}=200,39)$, а меншим - у тих, хто обрав багатство $(\mathrm{Rcep}=91,29)$ і впливовість $(\mathrm{Rcep}=123,22)$; проміжне місце зайняли творча самореалізація $(\mathrm{Rcep}=140,57)$ та кар'єра $(\mathrm{Rcep}=143,42)$. Для молоді, яка обрала добрі стосунки, соціальне визнання та професіоналізм, важливим $є$ збереження добрих стосунків з тими людьми, з якими вона перебуває в особистому контакті (див. рис. 2).

Не проявився зв'язок цінностей традиції і доброзичливості 3 такими чинниками досягнення успіху, як удача, ризик, виваженість, соціальні зв'язки та загальноприйняті норми і правила.

Універсалізм як цінність найбільший відгук має в молоді, що обрала як мірило життєвого успіху соціальне визнання $(\mathrm{Rcep}=171,25)$ i професіоналізм $(\mathrm{Rcep}=189,5)$, а найменший - у тих, хто обрав впливовість $(\operatorname{Rcep}=127,14)$ і кар'єру $(\operatorname{Rcep}=117,63)$. Для тієї молоді, що обрала добрі стосунки $(\mathrm{Rcep}=159,65)$, творчу самореалізацію $(\mathrm{Rcep}=158,88)$ i багатство (Rcep = 149), універсалізм не має великого значення в житті. Порівняльний аналіз за Н-критерієм Краскела - Уоллеса показав, що між цими групами молоді відмінності $є$ значущими (див. рис. 2). Молодь, що обрала соціальне визнання і професіоналізм, можна охарактеризувати як таку, що прагне опікуватися добробутом людей і пробле- 
мами збереження навколишнього середовища. На їі думку, ризик не відіграє вирішальної ролі в досягненні успіху, а більше сприяє цьому виваженість у вчинках $(\mathrm{r}=0,119, \mathrm{p}<0,05)$.

Цінність самостійності найбільше проявилася в молоді, що обрала професіоналізм $(\operatorname{Rcep}=184,17)$ і творчу самореалізацію $(\mathrm{Rcep}=174,54)$, найменше - у тих, хто обрав багатство $(\mathrm{Rcep}=136,83)$, добрі стосунки $($ Rcep $=141,79)$ і кар'єру $($ Rcep $=143,36)$, а впливовість $(\operatorname{Rcep}=152,06)$ i соціальне визнання (Rcep $=153,75)$, відповідно, зайняли проміжне місце. Відмінності за Н-критерієм Краскела - Уоллеса між цими групами молоді проявилися на рівні тенденції, тому ми додатково застосували порівняльний аналіз за U-критерієм Манна - Уітні. Це дало змогу уточнити значущі відмінності між групами молоді, що обрала добрі стосунки $($ Rcep $=90,2)$ і творчу самореалізацію $($ Rcep $=111,33, \mathrm{p}<0,05)$, а також добрі стосунки $(\mathrm{Rcep}=72,23)$ і професіоналізм $(\mathrm{Rcep}=91,89, \mathrm{p}<0,05)$ (рис. 3). Це говорить про те, що цінність самостійності найбільш приваблива для молоді, що обрала як показник життєвого успіху професіоналізм і творчу самореалізацію. Відповідно, цю частину молоді можна охарактеризувати як таку, що прагне автономності в різних сферах життєдіяльності, незалежно від того, чи це професійна діяльність, чи взаємодія зі своїм оточенням.

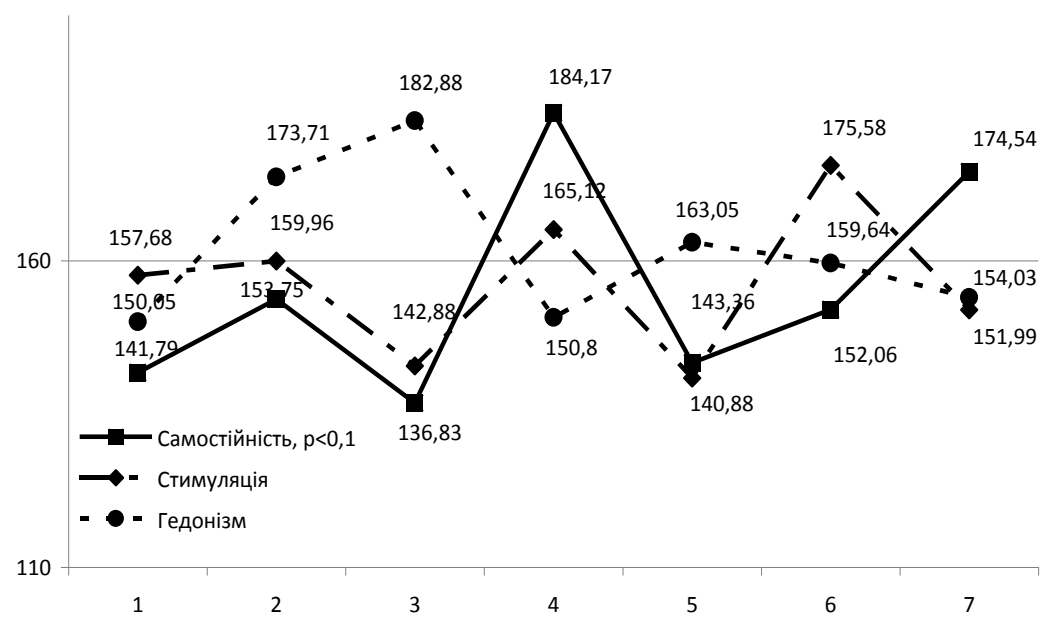

Примітки: 1 - добрі стосунки, 2 - соціальне визнання, 3 - багатство, 4 - професіоналізм, 5 - кар'єра, 6 - впливовість, 7 - творча самореалізація.

Рис. 3. Розподіл значень за методикою вивчення цінностей особистості Шварца залежно від життєвих орієнтирів,

які молодь обрала як показник життєвого успіху

(Н-критерій Краскела - Уоллеса, Rcep) 
Для молоді $з$ вираженими цінностями самостійності соціальні зв'язки в досягненні успіху мають найменше значення, така молодь більше покладається на саму себе $(\mathrm{r}=0,160, \mathrm{p}<0,01)$ у досягненні успіху. При цьому молоді люди впевнені в тому, що досягнуть успіху $(\mathrm{r}=-0,166, \mathrm{p}<0,01)$, і визнають, що їм $є$ чим пишатися у своєму житті $(\mathrm{r}=0,111, \mathrm{p}<0,05)$. Ця молодь відкрита до свого оточення і ділиться 3 ним своїми успіхами, а це означає, що в неї немає якихось побоювань щодо цього оточення $(\mathrm{r}=-0,144, \mathrm{p}<0,05)$ (див. рис. 3). Стимуляція як цінність найбільше значення має для молоді, яка мірилом життєвого успіху вважає впливовість $($ Rcep $=175,58)$, професіоналізм $($ Rcep $=65,12)$, a найменше - багатство (Rcep $=142,88)$ і кар'єру $($ Rcep $=140,88)$. Проте значущі відмінності між цими групами молоді не проявилися. Водночас молодь, у якої високі показники цінності стимуляції, вважає, що в досягненні успіху велику роль відіграє ризик $(\mathrm{r}=-0,116, \mathrm{p}<0,05)$, а щодо свого успіху демонструє впевненість у його досягненні $(\mathrm{r}=-0,120$, $\mathrm{p}<0,05)$.

Такі самі результати виявилися і щодо цінності гедонізму - між цими групами молоді такі відмінності не проявилися (див. рис. 3). Найбільше значення ця цінність має для молоді, що обрала соціальне визнання $(\operatorname{Rcep}=173,71)$ і багатство $(\mathrm{Rcep}=182,88),-$ у іï житті важливе місце займає насолода, або чуттєве задоволення, а найменше значення цінності гедонізму мають для тих, хто обрав добрі стосунки $(\mathrm{Rcep}=150,05)$, професіоналізм $(\mathrm{Rcep}=150,8)$ і творчу самореалізацію $(\mathrm{Rcep}=154,03)$. Ця ж молодь демонструє задоволення своїми досягненнями в житті $(\mathrm{r}=-0,117, \mathrm{p}<0,05)$.

Досягнення як цінність, що відображає важливість особистого успіху відповідно до соціальних стандартів (рис. 4), найбільшою мірою виражене у молоді, що обрала соціальне визнання $(\mathrm{Rcep}=185,04)$, кар'єру $(\mathrm{Rcep}=179,74)$ і професіоналізм $(\mathrm{Rcep}=172,76)$, а найменшою у тих, хто обрав творчу самореалізацію $(\mathrm{Rcep}=141,4)$ і багатство $(\mathrm{Rcep}=142,96)$. Проте порівняння цих груп за Н-критерієм КраскелаУоллеса значущих відмінностей не виявило, тому для уточнення було застосовано U-критерій Манна - Уітні, що виявив значущі відмінності між молоддю, що обрала кар'єру (Rcep $=67,12)$, і молоддю, що віддала перевагу творчій самореалізації ( $\mathrm{Rcep}=53,5, \mathrm{p}<0,05)$. Для молоді, у якої більш вираженою $є$ цінність досягнення, характерна впевненість у досягненні успіху в майбутньому $(\mathrm{r}=-0,238, \mathrm{p}<0,01)$ і задоволеність своїми теперішніми досягненнями $(\mathrm{r}=-0,155, \mathrm{p}<0,05)$.

Сприйняття влади як цінності найбільшою мірою проявляється в молоді, що визнає мірилом життєвого успіху багатство $(\mathrm{Rcep}=206,25)$ і впливовість $($ Rcep $=214,83)$, а найменшою - у тих, хто обрав творчу самореалізацію $(\mathrm{Rcep}=125,73)$ (див. рис. 4). У молоді, що обрала добрі стосунки $(\mathrm{Rcep}=150,52)$, соціальне визнання $(\mathrm{Rcep}=177,67)$, профе- 
сіоналізм $(\operatorname{Rcep}=163,52)$ і кар'єру $(\operatorname{Rcep}=172,86)$, прояв цього типу цінностей на середньому рівні. Тому можна стверджувати, що молодь, яка обрала багатство і впливовість, визнає найбільш важливим у своєму житті досягнення владного статусу, контролю або домінування над людьми, тоді як та частина молоді, що обрала творчу самореалізацію, вважає владу найменш важливою цінністю. Водночас цінність влади пов'язана з упевненістю молоді в досягненні успіху в майбутньому $(\mathrm{r}=-0,125, \mathrm{p}<0,05)$ і з визнанням того факту, що в неї $\epsilon$ досягнення, якими вона може пишатися $(\mathrm{r}=-0,210, \mathrm{p}<0,01)$.

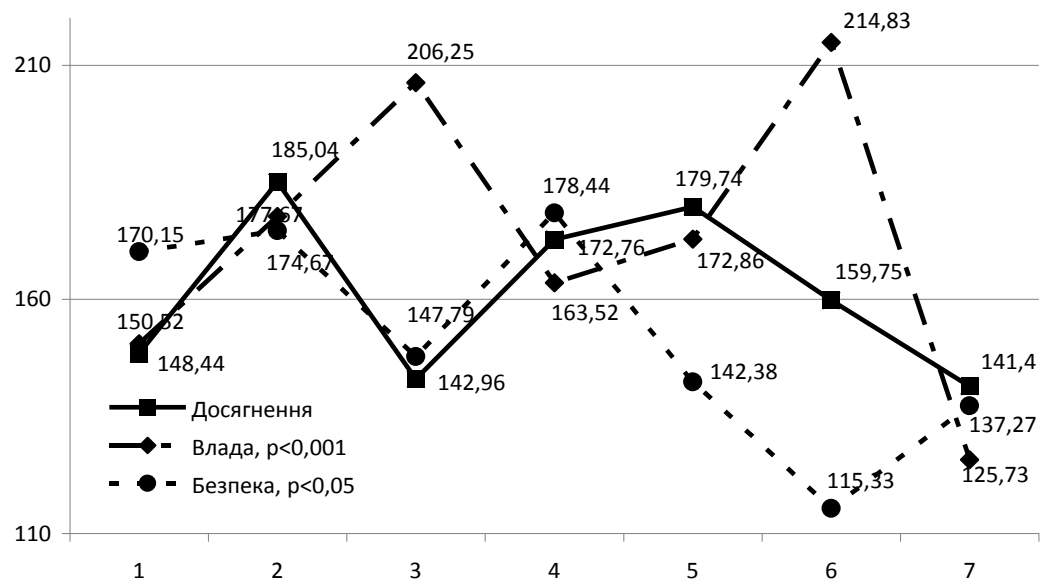

Примітки: 1 - добрі стосунки, 2 - соціальне визнання, 3 - багатство, 4 - професіоналізм, 5 - кар'єра, 6 - впливовість, 7 - творча самореалізація.

Рuc. 4. Розподіл значень за методикою вивчення цінностей особистості Шварца залежно від життєвих орієнтирів, які молодь обрала як показник життєвого успіху (Н-критерій Краскела - Уоллеса, Rcep)

Безпека як тип цінностей найбільш важлива для молоді, що обрала як показник життєвого успіху професіоналізм (Rcep = 178,44), соціальне визнання $(\mathrm{Rcep}=174,67)$ і добрі стосунки $(\mathrm{Rcep}=170,15)$, a найменш важлива - для тих, хто віддав перевагу впливовості $(\mathrm{Rcep}=115,33)$ (див. рис. 4). Важливість безпеки як цінності свідчить про те, що для цієї молоді на першому місці стоїть власна безпека та безпека інших людей, а також стабільність відносин з оточенням. У тієї молоді, що обрала багатство $(\mathrm{Rcep}=147,79)$, кар'єру $(\mathrm{Rcep}=142,38)$ i творчу самореалізацію $(\mathrm{Rcep}=137,27)$, цей тип цінностей не займає важливого місця в їхньому житті. Безпека, як і у випадку цінності 
досягнення, пов'язана з упевненістю молодих людей у досягненні успіху $(\mathrm{r}=-0,113, \mathrm{p}<0,05)$ і їхньою задоволеністю своїми теперішніми досягненнями $(\mathrm{r}=-0,149, \mathrm{p}<0,01)$, а також із визнанням того, що в них $\epsilon$ успіхи, якими вони можуть пишатися $(\mathrm{r}=-0,154, \mathrm{p}<0,01)$.

Утім, не було виявлено зв'язку між цінностями гедонізму, досягнення, влади і безпеки, з одного боку, і такими чинниками досягнення успіху, як удача, ризик, виваженість, соціальні зв'язки та загальноприйняті норми і правила, - із другого боку. Це свідчить про те, що зазначені цінності не пов'язані із цими чинниками. Водночас вони асоціюються з упевненістю в досягненні успіху і задоволеністю своїми досягненнями.

Висновки. Отже, життєві орієнтири, які є головним складником уявлень молоді про життєвий успіх, пов'язані з ціннісною сферою особистості. Для добрих стосунків, які молодь вважає мірилом життєвого успіху, характерні найбільшою мірою такі цінності: конформність, традиції, доброзичливість, безпека, а найменшою мірою - самостійність і гедонізм. Така вираженість цінностей свідчить про те, що для молоді, яка головним життєвим орієнтиром вважає добрі стосунки, характерна тенденція до консерватизму та самотрансцендентності. Така молодь не прагне різких змін у своєму житті, уникає ризиків і покладається на добре перевірені стратегії досягнення успіху. Для неї більшу вагу мають не власні досягнення, а добробут їхнього оточення.

Соціальне визнання як життєвий орієнтир, якому в структурі уявлень молоді про життєвий успіх належить провідне місце, тяжіє до самотрансцендентності, основою якої $є$ цінності доброзичливості й універсалізму. Проте в ціннісній сфері проявилися дві протилежні за змістом тенденції: одна 3 них пов'язана із цінностями конформності, традиції та безпеки, що корелють 3 консерватизмом, друга ж - із самозвеличенням, що знаходить відображення в гедонізмі і досягненні. Тобто соціальне визнання може досягатися або шляхом урахування норм і приписів оточення, або ж шляхом неординарних вчинків, що можуть суперечити загальноприйнятим правилам.

Для молоді, що обрала за життєвий орієнтир багатство, важливими цінностями $є$ конформність, гедонізм і влада, а менш важливими доброзичливість, традиція, самостійність, стимуляція і досягнення. Зв’язок багатства 3 конформністю, що $\epsilon$ складовою консерватизму, свідчить про те, що в уявленнях молоді склався спрощений образ успіху, навіяний найчастіше оточенням або ЗМІ, а зв'язок із цінностями гедонізму і влади відбиває тенденцію до самозвеличення. В уявленнях цієї молоді багатство часто постає як єдиний інструмент подолання життєвих негараздів.

Професіоналізм як життєвий орієнтир найщільнішим чином пов’язаний із цінностями конформності, традиції, доброзичливості, універ- 
салізму, самостійності, стимуляції, досягнення і безпеки. Такий широкий спектр цінностей говорить про те, що в професіоналізмі молодь вбачає універсальний інструмент реалізації своїх життєвих планів. Тому незалежно від того, якими ціннісними орієнтирами керується молодь, професіоналізм дає їй змогу досягти бажаного рівня життєвого добробуту відповідно до своїх життєвих цінностей.

Кар'єра - важливий життєвий орієнтир в уявленнях молоді, пов'язаний із цінностями конформності й досягнення. Таке поєднання цінностей свідчить про те, що образ кар'єри, з одного боку, як і у випадку з багатством, може бути навіяний оточенням або ЗМІ і поставати у спрощеному вигляді, а 3 другого - цей образ може бути привабливий для молоді, адже успішна кар'єра дає багато переваг у вигляді соціального статусу, доступу до необхідних ресурсів.

3 погляду впливовості на уявлення про життєвий успіх важливими є цінності стимуляції і влади, що відображають прагнення займати відкриту позицію щодо нового і прагнення самозвеличення. Ця частина молоді хоче посідати впливову позицію у своєму оточенні, не зупиняючись, однак, на чомусь одному, а для цього постійно використовує різні стратегії досягнення успіху.

Для молоді, що обрала творчу самореалізацію як життєвий орієнтир, важливою $є$ цінність самостійності, яку можна вважати складником відкритості до змін. Молоді люди прагнуть зберігати незалежність й автономність у своїй діяльності й відносинах, тому ця цінність має для них велике значення, а творча самореалізація дає можливість утілити їі у своє життя.

Перспективи подальших досліджень ми вбачаємо в тому, що виявлений зв'язок цінностей та уявлень про життєвий успіх допоможе краще осмислити проблеми, з якими доводиться стикатися молоді в період свого дорослішання. Продовження емпіричного дослідження дасть змогу віднайти оптимальні способи розв'язання цих проблем.

\section{Список використаних джерел}

1. Мелащенко, К. (2009). Життєвий успіх у гендерному вимірі: соціологічні розвідки. Сочіальні виміри суспільства, (12), 208-220.

2. Андросенко, М.Э. (2012). Психосемантический анализ представлений предпринимателей об успешности. Мир образования - образование в мире, (1), 205-211.

3. Гудзенко, О. 3. (2010). Міжпоколінські відмінності уявлень про фактори досягнення життєвого успіху. Соціологія майбутнього: науковий журнал з проблем сочіологї молоді та студентства, (1), 106-113.

4. Шамионов, Р. М., \& Тугушева А. Р. (2009). Представления о социальной успешности и самоопределении молодежи. Психологическая наука $u$ образование, 3. Взято из $\mathrm{http}: / /$ psyedu.ru/journal/2009/3/Shamionov_ Tugusheva.phtml. 
5. Карандашев, В.Н. (2004). Методика Шварияа для изучения иенностей личности: концепция и методическое руководство. Санкт-Петербург: Речь.

\section{References}

1. Melashchenko, K. (2009). Zhyttievyi uspikh u hendernomu vymiri: sotsiolohichni rozvidky [Gender dimension of life success: sociological research]. Sotsialni vymiry suspilstva [Social dimensions of society], (12), 208-220 (ukr).

2. Androsenko, M.E. (2012). Psikhosemanticheskiy analiz predstavleniy predprinimateley ob uspeshnosti [Psychosemantic analysis of businessmen representations about success]. Mir obrazovaniya - obrazovaniye v mire [World of education - education in the world], (1), 205 - 211 (rus).

3. Hudzenko, O. Z. (2010). Mizhpokolinski vidminnosti uiavlen pro faktory dosiahnennia zhyttevoho uspikhu [Transgenerational differences in representations off actors of achieving life success]. Sotsiolohiia maibutnoho: naukovyi zhurnal $z$ problem sotsiolohii molodi ta studentstva [Sociology of the future: scientific journal on sociological issues of youth and students], (1), 106-113 (ukr).

4. Shamionov, R. M., \& Tugusheva, A. R. (2009). Predstavleniya o sotsialnoy uspeshnosti i samoopredelenii molodezhi [Representations of social success and self-determination of youth]. Psikhologicheskaya nauka $i$ obrazovaniye [Psychological science and education], 3. Retrieved from http://psyedu.ru/ journal/2009/3/Shamionov_Tugusheva.phtml (rus).

5. Karandashev, V. N. (2004). Metodika Shvartsa dlya izucheniya tsennostey lichnosti: kontseptsiya $i$ metodicheskoye rukovodstvo [Schwartz Questionnaire for Studying Personality Values: Concept and Methodological Guide]. St. Petersburg: Rech (rus).

(C) Вінков В. Ю. 